\title{
Student Perception of School Health Environment in SMA 2 State Unggulan Talang Ubi Regency Pali
}

\author{
Ayu Agres Lestari ${ }^{1}$, Budi Utomo ${ }^{2}$ \\ Geography Education, University of PGRI Palembang ${ }^{12}$ \\ ${ }^{2 *}$ budi.banilasmin@gmail.com
}

\begin{abstract}
Lack of student awareness about the importance of environmental health causes school hygiene to become unhealthy. To find out students' perceptions about the health of the school environment in SMA Negeri 2 Unggulan Talang Ubi, Pali Regency.

The method used in this research is descriptive qualitative method. The population in this study all class X students in SMA Negeri 2 Talang Ubi Pali Regency, amounting to 157 people. Determination of the sample using a random sampling technique where individuals selected randomly into a sample of 30 people from all grade X students in SMA Negeri 2 Unggulan Talang Ubi, Pali Regency. Data collection techniques used in this study were observation, documentation and questionnaires. The validity of the data used in this study is triangulation of data collection techniques by checking data to the same source with different techniques to get data from the same source and analyze data using the percentage formula.

Based on the results of research that has been carried out to determine students' perceptions about school environmental health in SMA Negeri 2 Featured Talang Ubi in Pali Regency related to knowledge, understanding, attitudes and behavior of school environmental health by $75 \%$ have the perception that school environmental health is very important to maintain and creating environmental hygiene and health needs student selfawareness that starts with personal hygiene because if the school environment is not clean and healthy, disease transmission can occur through environmental media.
\end{abstract}

Keywords: Perception, School Environmental Health

\section{Introduction}

In Law No. 9 of 1960, regarding the points of Health, Chapter 1 article 2, Health is a condition that includes physical, spiritual (mental) and social health, and not only conditions that are free from disease, weakness. Whereas in the Law of the Republic of Indonesia No. 23 of 1992 concerning Health Chapter 1 Article 1, Health is the welfare of the body, soul and socially productive socially economically (Soemirat, 2011: 6-7).

Individual participation is very important in environmental health, ordinary hanayas are healthy if they work on it themselves. In addition, this healthy behavior is not enough to be carried out by only a few people, at least $80 \%$ of all people must participate in healthy 
behavior, because if not, transmission of the disease still occurs through various environmental media (Soemirat, 2011:7).

According to Soemirat (2011: 45) the environment is everything that is around it, whether in the form of inanimate objects, tangible objects, or abstract, including other humans. The importance of the environment in supporting the health of the school environment requires that environmental management be carried out in such a way as to remain healthy, so that it can sustainably support the lives of future generations.

General understanding of the school environment is one of the physical, mental and social unity of the school that meets the health requirements so that it can support the teaching and learning process properly and support the process of student growth and development optimally.

For students, of course, teaching and learning activities require a comfortable, clean school environment and enough trees.

From the researchers' observations of a number of class $X$ students and a teacher at Talang Ubi Featured High School 2 in Pali Regency who live in the Talang Ubi Kelurahan area. The environment at SMA Negeri 2 Unggulan Talang Ubi in the Regency of Pali looks quite clean, but because of the lack of knowledge and awareness of students about the importance of environmental health, it causes school hygiene to become unhealthy. This can be seen in less clean toilets, classrooms that are still a lot of dust and rubbish scattered, especially in drawers and under desks. Not only that the school field environment is also still a pile of garbage because during recess there are still students who litter, even though the school has provided a garbage dump.

To create a clean and healthy environment, principals and teachers should direct all students to do cleaning every day, reprimand students who are still doing things that make the environment not clean and healthy, especially around the school environment, noting students who throw garbage carelessly in a pocket book / book of violations, and make a new code of conduct concerning giving fines to students each violating one school code of conduct. This is done so that all students are more aware of the importance of the health of the school environment and avoid dangerous diseases, the environment becomes healthier. Not only is the community healthy, the whole school is more comfortable in carrying out its activities and the school environment becomes cleaner. 
The term perception comes from English perception which means observation. Everyone has a different understanding of a problem that they face, so that it will also affect the response to various problems that arise.

According to Slameto (2010: 102), Perception is a process that involves the entry of messages or information into the human brain. Through human perception, a relationship with its environment is continuously made. This relationship is done through its senses, namely the sense of sight, touch, taste, and smell.

According to Walgito (2010: 99) defines perception is a process that is preceded by a sensing process that is a process of receiving stimulus by individuals through sensory devices or also called sensory processes. According to Branca 1964 (in Walgito, 2010: 99), that perception is Organizing, interpreting the stimulus in its senses so that it is something meaningful and is an integrated response in individuals. According to Hamalik (2014: 20) in a broad sense, the environment is a system called an ecosystem, which includes all environmental factors, which are aimed at improving the quality of life on this earth.

According to Soemirat (2011: 45) Environment is everything that exists around it in the form of living things, inanimate objects, real or abstract objects, including other human beings, as well as the atmosphere that is formed due to interactions between these elements. According to Law No. 32 of 2009 concerning environmental management, Chapter 1 Article 1, The environment is a unity of space with all objects, power, conditions and living things, including humans and their behavior, which affect nature itself, the continuity of life and welfare of humans and other living creatures.

So from the above opinion it can be concluded that the notion of the environment is a unity of space with all objects and a system called ecosystems, whether in the form of living objects, inanimate objects, tangible or abstract objects, including other humans, and the atmosphere formed due to interactions between element.

According to Soemirat (2011: 13) environmental health can be interpreted as a science that studies the interaction between the environment with the health of humans, plants, and animals with the aim of increasing beneficial or eugenic environmental factors and controlling adverse or dysgenic factors, such that the risk of disturbance health and safety are under control.

According to WHO (World Health Organization) environmental health is an ecological balance that must exist between humans and the environment in order to guarantee the 
healthy state of humans. Indicators of School Environmental Health include: Knowledge, Understanding, Attitudes and Behavior.

\section{Research Methode}

According to Arikunto (2010: 173) Population is the whole subject of research. The population in this study were all students of class $X$ in SMA Negeri 2 Talang Ubi, Pali Regency, totaling 157 people.

The sample is part or representative of the population studied (Arikunto, 2010: 174). Meanwhile, according to Sugiyono (2011: 118) the sample is part of the number and characteristics possessed by the population. In this study sampling uses a random sampling technique which is a sampling technique where all individuals in the population either individually or together are given the same opportunity to be selected as sample members. The study was conducted on the population of the entire class X SMA Negeri 2 Unggulan Talang Ubi Pali Regency totaling 30 people using random sampling techniques.

In a study a method or method is needed so that the research is more directed and can facilitate the research process itself.

According Sukamti (2011: 17) The method can be interpreted as a systematic activity, planned by researchers to be able to solve problems that are alive and useful for the community or for researchers. Meanwhile, according to Arikunto (2013: 203) Research Methods are the methods used by researchers in gathering research data. Research is important for researchers to solve problems or answer questions about the phenomena in their environment.

The method used in this study is a qualitative descriptive method, where the qualitative descriptive method is a system of analyzing data by linking and analyzing existing facts and comparing existing theories with the implementation carried out by an education using a questionnaire, then checked by observation and documentation.

According to Arikunto (2006: 120), "Data collection techniques are ways that can be used by researchers for data collection".

Data collection techniques are the best and strategic step in a study, because the main purpose of research is to get data. Data collection techniques used in this study were observation, documentation and questionnaires. 
According to Singarimbun, (2006: 263) Data analysis is the process of simplifying data into a form that is easier to read and interpreted in this process often used statistics, one of the main functions of statistics is the simplification of very large amounts of research data into simpler and easier information to understand.

According to Sugiyono (2014: 89) Data analysis is the process of systematically searching and compiling data obtained from interviews, field notes, and documentation, by organizing data into categories, describing into units, synthesizing, compiling into patterns, selecting which are important and which will be learned, and make conclusions so that they are easily understood by themselves and others.

The process of data analysis begins by examining all data obtained through the results of a questionnaire, observation and documentation.

Data analysis was carried out several stages starting with distributing questionnaires, editing to see the completeness of the identity and data of respondents and ensuring all answers that have been filled in, followed by providing a code to facilitate researchers in tabulating data and subsequently scoring, in this scoring the tools used is a Likert scale which is one way to determine the score, this Likert scale is divided into 2, namely positive and negative, for positive questions is strongly agree $=5$, agree $=4$, doubtful $=3$, disagree $=2$, strongly disagree agree $=1$, the score for negative questions is strongly agree $=1$, agree $=2$, doubt $=3$, disagree $=4$, strongly disagree $=5$ (Riduwan dan Sunarto,2013:21) .

Then do the data calculation using the percentage formula.

$$
\begin{aligned}
& \mathrm{P}=\frac{\mathrm{F}}{N} \times 100 \% \quad \text { (Sudjiono, 2009:43) } \\
& \mathrm{F}=\text { The frequency } \\
& \mathrm{N}=\text { Number of cases } \\
& \mathrm{P}=\text { percentage value }
\end{aligned}
$$

The results obtained previously that are qualitative are processed into quantitative data by matching the percentage values with the following evaluation criteria.

\section{Results and Discussion}

Students' perceptions about the health of the school environment in SMA Negeri 2 Unggulan Talang Ubi Pali Regency are the opinions or responses of students regarding environmental health of schools in SMA Negeri 2 Unggulan Talang Ubi, Pali Regency. 
environmental health is the study of interactions between the environment and the health of humans and the conditions of various environmental media affect public health.

Distribution of questionnaires or questionnaires conducted on 30 respondents who in the case of students who are in the school environment of SMA Negeri 2 Unggulan Talang Ubi Pali Regency, the distribution of this questionnaire was carried out in order to determine students' perceptions about the health of the school environment at SMA Negeri 2 Unggulan Talang Ubi Pali Regency seen from the side of knowledge, understanding, and attitudes and behavior of students.

From the description of a single variable in this study can be described as follows:

63666769696970717272

75757576777777787878

78787879798080818182

The highest score : 82

Lowest score : 63

Range $\quad=$ The highest score - Lowest score

$$
=82-63
$$$$
=19
$$

Class Length $=$ Range $:$ Sum of Classes

$$
\begin{aligned}
& =19: 5 \\
& =3,8 \text { rounded to } 4
\end{aligned}
$$

Table 1. Interval School of Health Environment

\begin{tabular}{|c|c|c|c|c|}
\hline Interval & Frekuensi & Classes & Assessment criteria & $(\%)$ \\
\hline$>82$ & 1 & V & Very Good & $3,3 \%$ \\
\hline $76-81$ & 16 & IV & Good & $53,3 \%$ \\
\hline $70-75$ & 7 & III & Moderate & $23,3 \%$ \\
\hline $65-69$ & 5 & II & Bad & $16,7 \%$ \\
\hline $59-64$ & 1 & I & Very Bad & $3,3 \%$ \\
\hline
\end{tabular}

From 30 students, the results show that students' perceptions about the health of the school environment in SMA Negeri 2 Featured Talang Ubi in Pali Regency are included in very good criteria 1 person is around $3.3 \%$, good 16 people is around $53.3 \%$, Moderate 7 
people which is around $23.3 \%$, Bad 5 people which is around $16.7 \%$, and Very Bad 1 person which is around $3.3 \%$.

For more details, see the following Picture 1:

Picture 1. Interval School Of Health Environment

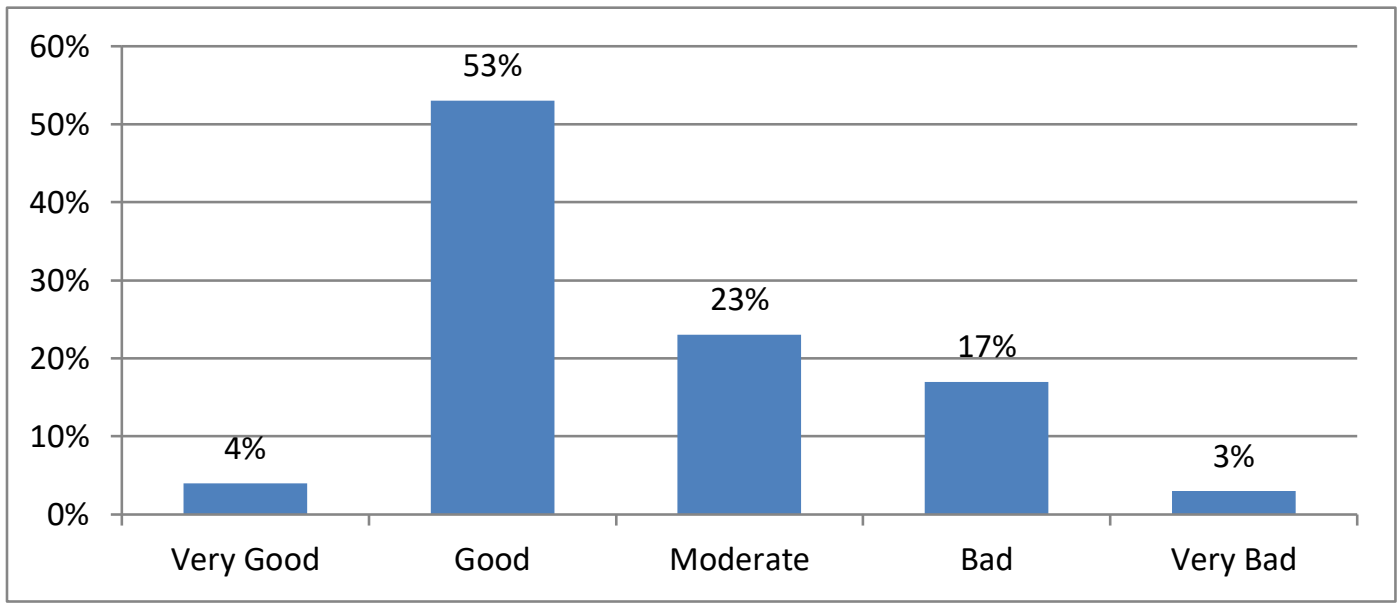

From the Picture 1 above, it can be concluded that $4 \%$ of students already know, understand and have very good behavioral attitudes about the health of the school environment in SMA Negeri 2 Featured Talang Ubi Pali Regency, by 53\% students already know, understand and have good behavioral attitudes about the health of the school environment in SMA Negeri 2 Featured Talang Ubi Pali Regency, amounting to 23\% of students already know, understand and have a fairly good attitude about the health of the school environment in SMA Negeri 2 Unggulan Talang Ubi Pali Regency, 17\% of students already know, understand and have unfavorable attitudes about the health of the school environment in SMA Negeri 2 Unggulan Talang Ubi, Pali Regency, and 3\% of students already know, understand and have bad behavior about the health of the school environment in SMA Negeri 2 Unggulan Talang Ubi Pali Regency. Based on the description above, then the percentage score based on a Likert scale measure that has been calculated using the average percentage formula obtained or can be as much as $75 \%$ of students already know, understand and have a fairly good attitude about the health of the school environment in SMA Negeri 2 Featured Talang Ubi in Pali Regency, according to the criteria stated by arikunto that overall students know and understand about the health of the school environment is good enough. The data above is reinforced by information from the quotation results of interviews conducted on September 2, 2015 with Mr. Irwansyah, S.Pd, M.Si Principal of the Secondary High School Talang Ubi Pali Regency that knowledge, understanding, students' attitudes and behaviors about environmental health are good enough 
because students already know the school's environmental health problems and harmful diseases, students are good enough to understand how to create a clean and healthy environment, students already have good enough attitudes and behaviors towards environmental health.

From the results of observations by researchers of a number of class $\mathrm{X}$ students and a teacher in Talek Ubi Featured 2 High School in Pali Regency who live in the Talang Ubi Kelurahan area. The environment at SMA Negeri 2 Unggulan Talang Ubi in the Regency of Pali looks quite clean, but because of the lack of knowledge and awareness of students about the importance of environmental health, it causes school hygiene to become unhealthy. This can be seen in less clean toilets, classrooms that are still a lot of dust and rubbish scattered, especially in drawers and under desks. Not only that the school field environment is also still a pile of garbage because during recess there are still students who litter, even though the school has provided a garbage dump. This study is in line with research conducted by Renny Anggraini (2014) entitled Student Perceptions of School Environmental Health in Palembang's Perintis Middle School, because the results are obtained. Renny Anggraini (2014) the results obtained were $71.83 \%$ of students already knew, understood, and have a fairly good attitude and behavior about school environmental health in Palembang Perintis Middle School and the results obtained by researchers $75 \%$ of students already know, understand and have a fairly good attitude and behavior about school environmental health in SMA Negeri 2 Unggulan Talang Ubi Pali Regency. This research can be said to be in line with the research of Renny Anggraini (2014) because it can be seen from the results obtained that students already know, understand, and have a fairly good attitude and behavior about the health of the school environment.

This research is not in line with research conducted by Yoni Hermawan and Komara Nur Ikhsan in the journal The Effect of Environmental Health Counseling on the Level of Knowledge and Implementation of Environmental Health at Tambaksari State Junior High School in Tambaksari District of Ciamis District, because of the different resultsThe results obtained by researchers by $75 \%$ of students already know, understand and have a fairly good attitude and behavior about the health of the school environment in SMA Negeri 2 Featured Talang Ubi Pali District while the results of Yoni Hermawan and Komara Nur Ikhsan the influence of environmental health education on the level of knowledge and the implementation of environmental health in one of Tambaksari Public Middle School, 
Tambaksari District, Ciamis Regency. The knowledge of students before being counseled at one of the Tambaksari Middle Schools, Tambak Sari Subdistrict, Ciamis Regency was mostly categorized quite well and the knowledge of students after being given education was mostly good. This research is also not in line with the research conducted by Wahyu Akbar in the Comparative Journal of UKS Activities with Health Enterprises in Cipageran Community Development Activity Center in North Cimahi District Cimahi City on Environmental Health of Cipageran Village, Cimahi City, because we get different results. The results obtained by researchers by $75 \%$ of students already know, understand and have a fairly good attitude and behavior about the health of the school environment in SMA Negeri 2 Featured Talang Ubi in Pali District while the results that Wahyu Akbar got were the UKS organizational mechanism at the Cipageran Learning Activity Center in Cimahi City including the good enough category with a percentage of $78.33 \%$ While in the Community Development Activity Center of Cipageran Community in Cimahi City is included in the less category with a percentage of $62.55 \%$, the implementation of the UKS work program at the Cimahi City Learning Center is included in the good category with a percentage of $83.49 \%$. While at the Cipageran Community Development Activity Center in Cimahi City, it belongs to the sufficient category with a percentage of $77.22 \%$ and the availability of UKS facilities and infrastructure. The Community Learning Activity Center in Cimahi City with the Cipageran Community Development Activity Center in Cimahi is quite good with a percentage of 66,67 $\%$.

\section{Conclusion}

The results of data analysis and discussion of students' perceptions of the health of the school environment in SMA Negeri 1 Talang Ubi, Pali Regency, it can be concluded that:

1. Students perceptions of the school's environmental health in SMA 2 Featured Talang Ubi Pali Regency which includes knowledge, understanding, attitudes and behavior of $75 \%$ including the criteria is good enough to have a perception that the school's environmental health is very important and to maintain and create cleanliness and environmental health needs student self-awareness that starts with personal hygiene because if the school environment is not clean and healthy, transmission of disease can occur through environmental media, and make teaching and learning activities comfortable. 
2. From the results of observations by researchers of a number of class $X$ students and a teacher at the Talang Ubi Featured 2 High School in Pali Regency who live in the Talang Ubi Kelurahan area. The environment at SMA Negeri 2 Unggulan Talang Ubi in the Regency of Pali looks quite clean, but because of the lack of knowledge and awareness of students about the importance of environmental health, it causes school hygiene to become unhealthy. This can be seen in less clean toilets, classrooms that are still a lot of dust and rubbish scattered, especially in drawers and under desks. Not only that the school field environment is also still a pile of garbage because during recess there are still students who litter, even though the school has provided a garbage dump.

3. From the results of these studies it turns out students perceive that the health of the school environment is very important for everyone, especially for themselves.

\section{Reference}

Arikunto, Suharsimi. 2010. Prosedur Penelitian Suatu Pendekatan Praktik. Jakarta: Rineka Cipta.

Ayu Agres Lestari. 2015. Persepsi Siswa Tentang Kesehatan Lingkungan Sekolah Di SMA Negeri 2 Unggulan Talang Ubi Kabupaten PALI Tahun Ajaran 2015/2016. (artikel jurnal). Palembang: Fakultas Keguruan dan Ilmu Pendidikan Universitas Persatuan Guru Republik Indonesia.

Hermawan, Yoni dan Ikhsan, Komara Nur.2011.Pengaruh Penyuluhan Kesehatan Lingkungan Terhadap Tingkat Pengetahuan dan Pelaksanaan Kesehatan Lingkungan SMP Negeri Tambaksari Kecamatan Tambaksari Kabupaten Ciamis. 166-169.

Riduwan, 2009.Rumus dan Data dalam Analisis Statistika. Bandung: Alfabeta.

Singarimbun, Masri dan Safiah Efendi. 2006. Metode Penelitian Survai. Jakarta Barat: Pustaka LP3ES Indonesia, Anggota IKAPI.

Slameto.2010. Belajar Dan Faktor-Faktor Yang Mempengaruhinya. Jakarta: Rineka Cipta.

Soemirat, Juli. 2011. Kesehatan Lingkungan. Yogyakarta: UGM Press.

Sudjiono, Anas. 2009. Statistik Pendidikan. Bandung: Alfabeta.

Sugiyono.2010 Metode Penelitian Pendidikan. Bandung: Alfabeta.

Sugiyono. 2010. Memahami Penelitian Kualitatif. Bandung: Alfabeta.

Walgito, bimo. 2010. Psikologi umum. Yogyakarta: CV. Andi Offset. 